\title{
Economic implications of different cork oak forest management systems
}

\author{
António Cipriano Pinheiro* \\ Departamento de Economia, \\ Universidade de Évora, \\ Largo dos Colegiais, 2, \\ Évora 7000-803, Portugal \\ E-mail: acap@uevora.pt \\ *Corresponding author
}

\section{Nuno Almeida Ribeiro and Peter Surový}

Departamento de Fitotecnia, Universidade de Évora, Largo dos Colegiais, 2, Évora 7000-803, Portugal E-mail: nribeiro@uevora.pt E-mail: psurovy@uevora.pt

\section{Alfredo Gonçalves Ferreira}

\author{
Departamento de Engenharia, \\ Universidade de Évora, \\ Largo dos Colegiais, 2, \\ Évora 7000-803, Portugal \\ E-mail: alfredo@uevora.pt
}

\begin{abstract}
The agro-silvopastoral system 'montado' is mostly dominated by Mediterranean evergreen oaks such as, cork oak (Quercus suber L.) and holm oak (Quercus rotundifolia). The 'montado' production system management aims the maintenance of a balanced sustainable land use to cope with the Mediterranean climate variability. One important issue in cork oak forests is the control shrub growth in order to prevent forest fire hazard, which is of high risk in Mediterranean climate. In this article, two shrub control systems are compared and the results show that although soil disking is more profitable than shrub cutting, the results are reversed, if one considers the carbon sequestration. This means that besides the great economic sustainability of cork oak dependence on the price of cork, the profitability of different shrub control methods depend also on the way society valuates other goods and services provided by cork oak forest.
\end{abstract}

Keywords: cork oak; dehesa; forest; montado; net present value; NPV; sustainability; woodlands.

Reference to this paper should be made as follows: Pinheiro, A.C., Ribeiro, N.A., Surový, P. and Ferreira, A.G. (2008) 'Economic implications of different cork oak forest management systems', Int. J. Sustainable Society, Vol. 1, No. 2, pp.149-157.

Copyright (C) 2008 Inderscience Enterprises Ltd. 
Biographical notes: António Cipriano Pinheiro received his $\mathrm{PhD}$ in Agricultural Economics from the Iowa State University. He is a full Professor at the University of Evora. He teaches undergraduate and graduate courses in agricultural economics, rural development and quantitative methods. For several periods, he has been an International Consultant for the Iinter-American Institute of Cooperation for Agriculture in Brazil. He has been an Independent Project Appraiser for research in the areas of common agricultural policy (CAP), Management of Agricultural Resources and Management of Living Resources, for projects financed by the European Commission. His research areas of interest include CAP and natural resources mainly water and forests.

Nuno de Almeida Ribeiro is a Researcher at the Institute for Mediterranean Agrarian Sciences (ICAM) and a Professor at the University of Évora, Portugal (Department of Crop Science). He has conducted research on tree growth and yield modelling mainly in pure and mixed cork oak stands. He has developed a single tree spatial growth simulator for cork oak (CORKFITS) and is currently developing an ecological based decision support system (ECCORK) for aid in management decisions for cork oak stands.

Peter Surový is a Post-doc Researcher in Instituto Superior de Agronomia de Lisboa and at the University of Evora in Portugal. He obtained his $\mathrm{PhD}$ in Forest Management and Geodesy in the Technical University of Zvolen Slovakia. He works in several research projects in both Slovakia and Portugal. His research interests are applied informatics in forestry, modelling and automatic image analysis. He has published in Journal of Forest Research, Advances in Geoecology, Revista Ciências Agrárias and chapters in various books.

Alfredo Gonçalves Ferreira is a Researcher at the Institute for Mediterranean Agrarian Sciences (ICAM) and a Professor at the University of Évora, Portugal (Department of Agriculture Engineering). He conducts research on soil conservation and sustainability of pure and mixed cork oak stands in order to develop a site rate system for Mediterranean oak stands.

\section{Introduction}

Portuguese climate and soil conditions indicate independently of economic reasons that large areas of the country are only suitable for forest or agro-forestry production systems. A study of the Portuguese soil use (SROA, 1970) concludes that only $28 \%$ of the country area was good for agriculture and most of the soil should be used as woodland.

Portuguese entrance in European Union increased the rate of the large areas of land which fell out of cultivation. In 1985, the number of agricultural farmers was 600,000 and presently, the number decreased to around 230,000.

The successive reforms of common agricultural policy (CAP) have clearly showed that most of the agricultural systems that had been practiced in Portugal were not economically viable. Therefore, large areas of land were left uncultivated. Presently, for most of those areas of the country, forest seems to be the only alternative to bring back land into production.

Presently, private and public landowners are facing challenges regarding society's view of forests and traditional forest management practices (Brunson, 1993). 
Although society as a whole is demanding a more holistic approach of forest and other natural resources management and many studies prove that private forest owners agree strongly with the managing of resources for future generations (see, for instance Creighton, Baumgartner and Blatner, 2002), most of the private landowners see forest, primarily, as an away of earning money.

In general, farmers are aware that forest and woodland benefits local communities and the society as a whole, by providing goods and services for which farmers, most of the times, receive nothing. More and more farmers realise that different management systems can have not only different economic implications but can also have great impact on use and non-use benefits, such as soil conservation, habitats and watershed maintenance for several species, recreational use, regulations of atmospheric quality, biodiversity and landscape amenities facilitates.

One important issue in cork oak forests is the control shrub growth to prevent forest fire hazard whose risk is very high in Mediterranean climate. The two most common ways to control the shrub component is by mechanical destruction with soil disking (that implicates soil mobilisation) or by shrub cutting (that is done with minimum impact on soil). The two referred techniques have different costs and impacts on cork production and other goods and services (multi-functionality) of cork oak forests.

In this article, the two shrub control systems are compared in their impacts on

1 the goods and services produced at stand level for a set multi-functionality indicators

2 the net income generated by both managing systems.

\section{Specificities of 'montado' woodlands in Mediterranean regions}

The agro-silvopastoral system 'montado' dominates the landscape of the south-western Iberian Peninsula, occupies approximately 3.1 million hectares of woodland in Spain (Díaz et al., 1997) and 1.2 million hectares in Portugal (DGF-IFN, 2001). The forest system 'montado' is mostly dominated by Mediterranean evergreen oaks such as cork oak (Quercus suber L.) and holm oak (Quercus rotundifolia). The 'montado' production system management aims the maintenance of a balanced sustainable land use to cope with the Mediterranean climate variability. The 'montado' stands are managed in agrosilvo-pasture systems of which sustainability depends on balanced relations between their components

1 Forest component managed for continuous crown cover to sustainably produce cork, acorn, wood, firewood and support productions of natural pasture, mushrooms, honey, natural habitat for hunting species and many more.

2 Pasture component based on an extensive livestock with the animals feeding directly on leaves, acorns and grass (from natural/artificial, temporary/permanent pasture systems) and complemented with stored cereal culture products that in some areas, is grown in long rotations (Campos, Rodríguez and Caparrós, 2001; Ribeiro et al., 2004; Ribeiro, Surovy and Oliveira, 2006).

The objective of continuous crown cover management can be jeopardised both by intensification of the undercover activities related to grazing (soil disking and undercover cultivation), which lead to a lack of regeneration and the consequent disappearance of the crown cover with a growing risk of soil erosion or by the extensification that leads to the 
stands invasion by shrubs and other oaks, increasing competition and the risk of forest fire. In fact, 'montado' systems are facing gradual decay of the tree canopy as the oaks age, because tree recruitment is insufficient to offset natural or management induced tree mortality. (Pulido, Díaz and Hidalgo, 2001; Ribeiro et al., 2004; Plieninger, 2007). Portugal and Spain failed to negotiate European Unions forestry integrated measures in the CAP in 1992 and 1999, reforms that would efficiently mitigate the failure of tree regeneration mainly because the production system 'montado' was never considered as a whole and only partial measures were financed resulting in an increased level on conflicting interests in the production system that resulted in an unbalanced livestock that is incompatible with natural/artificial regeneration.

The agro-silvopastoral system 'montado' ownership is characterised in Portugal by large private estates and multi-functional production of commercial and non-commercial goods and services. In addition to these traditional commercial uses, the 'montado', there are other benefits that are of growing interest to the society such as wildlife habitat, private amenities, public recreation opportunities, carbon storage and quality water production (Campos and Caparro's, 2006). Montado forest landscapes represent one of the best Mediterranean examples of the development of the multi-functional role of forests maintained over thousands of years. In these landscapes, high conservation value forest areas alternate with multipurpose farmland systems ${ }^{1}$.

In Portugal, cork oak forest occupies approximately 700.000 hectares of land, which makes Portugal the most important cork producer of the world (DGF-IFN, 2001).

Although cork oak fruits can be used to feed animals and some wood can be sold, the main source of income of this forest is cork. There are varying degrees of quality and the cork undergoes a strict quality selection process that determines its final use. The best quality cork is selected for bottle stoppers.

\section{Data and methodology}

Field data used in this study, namely cork production, cork prices, stripping off cork costs, forest planting or seeding costs, soil disking and shrub cutting costs were provided by the AGROREG ${ }^{2}$ ('Regeneração Natural e Artificial do Sobreiro e a Gestão Sustentada do Montado') project team and through cork oak farmer's association's consultation.

Given the nature of cork oak forest, the most significant part of income is derived a long period after planting (usually the first revenue from cork is obtain 28 years after planting). Cost-benefit analysis of such long-term investment is very sensitive to expected costs and revenues as well as to the discount rate used.

To estimate future productions, it was assumed that sustainable soil and plant management techniques will be used.

From the economic point of view, the most import product that can be obtained from cork oak trees is the cork to make corks for the wine industry, as it was referred before. There is a lot of competition in stoppers industry, but good wine producers continues to prefer corks although their prices are higher than most of its substitutes. Therefore, demand for cork is highly correlated with the demand for good wine. In Europe, wine consumption per capita is declining, but the demand for good wine is increasing. Presently, there is no reason to believe that cork future prices, in real terms will decline. Therefore, we assumed that prices will remain similar to those practiced during the last years. 
Table 1 Assumptions for cork oak investment

\begin{tabular}{llc}
\hline Year $(s)$ & Activity & Real cost/benefit $\left(€ \mathrm{ha}^{-1}\right)$ \\
\hline 0 & Site preparation and planting & $-1,200$ \\
$5-100$ (every fifth year) & Infesting control by soil disking & -60 \\
$3-100$ (every third year) & Infesting control by shrub cutting & -120 \\
$1-100$ & Annual revenue from cattle & 22.4 \\
28 & First cork production $177 \mathrm{~kg}$ & $235.41-589.41^{\mathrm{a}}$ \\
28 & Stripping off cost $\left(0.23 € \mathrm{~kg}^{-1}\right)$ & -40.71 \\
$37-100$ (every ninth year) & Cork production, approximately $1,900 \mathrm{~kg}$ & $2,527.00-6,327.00^{\mathrm{a}}$ \\
$37-100$ (every ninth year) & Stripping off cost $\left(0.23 € \mathrm{~kg}^{-1}\right)$ & -437 \\
\hline
\end{tabular}

a The revenue from cork selling depend of it quality. It is assumed that the price ranges from 1.33 to $3.33 € \mathrm{~kg}^{-1}$

Table 1 summarises the assumptions used in this study.

As it was said before, long-term investments are very sensitive to the discount rate used. Recently, some theorist's economists have begun to reach the conclusion that constant social discount rates are unjustified (Hepburn and Kaundouri, 2007). For instance, work surveyed in Groom et al. (2005) suggests that the correct social discount rate should actually vary with time, beginning with the short-term rate of $3.5 \%$ and declining over the long-run to $1 \%$ (Hepburn and Kaundouri, 2007). The choice of discount rate can often be critical in determining whether the project is acceptable using cost-benefit analysis or not. As society is perpetual, issues like social discount rates and intergenerational equity make a lot of sense. There is no doubt that social rate of time preference is smaller than the private one. In addition, society as a whole has more responsibility for leaving the stock of natural resources that can provide benefits for future generations than individual farmers. The reality shows that most of the farmers act as entrepreneurs whose main objective is maximise net present revenue. Therefore, to analyse the profitability of forest investment, it seems preferable to use constant rate of discount.

Although there is more sophisticated techniques of forest appraisal (Bullard and Straka, 1993), the method to be used in this study to analyse the forest investment profitability, is net present value (NPV), because we think it portrays accurately the value of forest investment.

The NPV of any investment can be estimated by

$$
\mathrm{NPV}=\sum_{i=0}^{i=T} \frac{R_{i}-C_{i}}{(1+r)^{i}}
$$

where, $R_{i}$ and $C_{i}$ are, respectively, the revenue and the expense occurred in year $i, r$ is the annual rate of discount and $T$ stands for the life of the investment. 


\section{Net present value estimation}

Considering the assumptions of Table 1, the NPV of the investment in cork oak production per hectare was estimated for both methods of eliminating shrub layer: soil disking and shrub cutting.

Table 2 shows that soil disking is more profitable than shrub cutting. Net present value, even for a $3 \%$ discounting rate for shrub cutting system only is positive if the price of cork is around $2 € \mathrm{~kg}^{-1}$ or greater.

As it was said before, forest in general and forest cork oak in particular is a multifunctional production ecosystem that can benefit society with many goods and services. Some of these goods and services are public goods or quasi public goods. Therefore, the producers, in general, cannot receive for them. Presently, society is more aware of the benefits provided by forest, as many studies prove (Gürlük, 2006). However, if farmers do not receive money or other type of incentives for producing those goods and services, they may not be produced.

Having in mind the results of Table 2, one can ask the following question: are these methods alike with respect to the amount of good and services that forest can produce? To answer this question all researchers involved in the project were asked to fill out, in Table 3, the row of his expertise. Columns 2 and 4 indicate the intensity and the direction that the expert thinks the event will occur and columns 3 and 5 indicates how sure the expert is about the event occurrence. The results are summarised in Table 3.

From Table 3, it is clear that shrub cutting is more beneficial for most of the items considered, namely for almost all aspects of biodiversity and site resource preservation. This method of infesting plants control can also led to a higher carbon sequestration. Recent studies show that one hectare of cork oak forest under soil disking sequesters 1 ton $\mathrm{ha}^{-1}$ year $^{-1}$, while the same area under shrub cutting can sequester 3 ton ha $^{-1}$ year $^{-1}$. If we consider the price of carbon as being $20 € \operatorname{ton}^{-1}$ and recalculates NPV under this assumption, the results obtained are shown in Table 4.

Comparing Tables 2 and 4, we can conclude that it is enough to consider the value of carbon sequestration to make shrub cutting more profitable than soil disking. This means that although the economic sustainability of cork oak depend greatly upon the price of cork, the profitability of different methods of controlling infesting plants depend also on the way society valuates other goods and services provided by cork oak forest.

Table 2 Net present value per hectare of cork oak forest (see online version for colours)

\begin{tabular}{|c|c|c|c|c|c|c|}
\hline \multirow{3}{*}{$\begin{array}{l}\text { Cork prices } \\
\text { per kg }(€)\end{array}$} & \multicolumn{6}{|c|}{ Discounting rates } \\
\hline & \multicolumn{3}{|c|}{ Soil disking } & \multicolumn{3}{|c|}{ Shrub cutting } \\
\hline & $3 \%$ & $5 \%$ & $7 \%$ & $3 \%$ & $5 \%$ & $7 \%$ \\
\hline 1.33 & 677.5 & -467.2 & -835.8 & -190.2 & -1006.9 & -1219.5 \\
\hline 2.00 & 1602.3 & -162.1 & -718.6 & 734.6 & -701.8 & -1102.3 \\
\hline 2.67 & 2527.1 & 143.1 & -601.4 & 1659.4 & -396.6 & -985.1 \\
\hline 3.33 & 3451.8 & 448.2 & -484.2 & 2584.2 & -91.5 & -867.9 \\
\hline
\end{tabular}


Table 3 Effects of two different shrub control methods on the quantity of goods and services provided by cork oak forest (see online version for colours)

\begin{tabular}{|c|c|c|c|c|}
\hline \multirow[b]{2}{*}{$\begin{array}{l}\text { Goods and services produced by cork } \\
\text { oak forest }\end{array}$} & \multicolumn{2}{|c|}{ Soil disking } & \multicolumn{2}{|c|}{ Shrub cutting } \\
\hline & $\begin{array}{l}\text { Increase (+) } \\
\text { Decrease (-) }\end{array}$ & $\begin{array}{l}\text { Degree of } \\
\text { confidence }\end{array}$ & $\begin{array}{l}\text { Increase (+) } \\
\text { Decrease (-) }\end{array}$ & $\begin{array}{l}\text { Degree of } \\
\text { confidence }\end{array}$ \\
\hline \multicolumn{5}{|l|}{ Goods and services with market } \\
\hline Cork & - & 1 & + & 2 \\
\hline Acorn & + & 1 & & \\
\hline Animals (cows, sheep, pigs) & + & 3 & - & 3 \\
\hline Mushrooms & --- & 4 & + & 3 \\
\hline \multicolumn{5}{|l|}{ Other goods (honey, asparagus...) } \\
\hline Number of regenerating plants & - & 3 & + & 3 \\
\hline Carbon sequestration & -- & 3 & ++ & 3 \\
\hline Hunters preferences & +- & 3 & +- & 3 \\
\hline Apiculture and aromatic plants & & 3 & & 3 \\
\hline \multicolumn{5}{|l|}{ Employment } \\
\hline Number of tractor hours /ha & - & 2 & + & 2 \\
\hline \multicolumn{5}{|l|}{ Biodiversity } \\
\hline Birds & - & 1 & + & 3 \\
\hline Insects & - & 2 & ++ & 4 \\
\hline Diversity of birds and insects & - & 2 & + & 3 \\
\hline Diversity of other species & + & 3 & ++ & 4 \\
\hline Quality of other species & -- & 4 & +++ & 5 \\
\hline \multicolumn{5}{|l|}{ Site resources preservation } \\
\hline Erosion protection & --- & 5 & +++ & 4 \\
\hline Water retention & -- & 4 & ++ & 3 \\
\hline Organic matter & --- & 4 & ++ & 4 \\
\hline Fire protection & + & 4 & - & 3 \\
\hline
\end{tabular}

Notes: Degree of confidence 5 means that the expert is absolutely sure. The number of signs + or - shows the magnitude of expected effect. The sign +- means neutral effect.

Table 4 Net present value considering carbon sequestration (see online version for colours)

\begin{tabular}{|c|c|c|c|c|c|c|}
\hline \multirow{3}{*}{$\begin{array}{l}\text { Cork prices } \\
\text { per kg }(\epsilon)\end{array}$} & \multicolumn{6}{|c|}{ Discounting rates } \\
\hline & \multicolumn{3}{|c|}{ Soil disking } & \multicolumn{3}{|c|}{ Shrub cutting } \\
\hline & $3 \%$ & $5 \%$ & $7 \%$ & $3 \%$ & $5 \%$ & $7 \%$ \\
\hline 1.33 & 1309.5 & -70.2 & -550.4 & 1705.8 & 184.0 & -363.3 \\
\hline 2.00 & 2234.3 & 234.9 & -433.2 & 2630.6 & 489.1 & -246.1 \\
\hline 2.67 & 3159.0 & 540.0 & -316.0 & 3555.3 & 794.2 & -129.0 \\
\hline 3.33 & 4083.8 & 845.1 & -198.9 & 4480.1 & 1099.4 & -11.8 \\
\hline
\end{tabular}




\section{Conclusions}

Although the time series data is not yet long enough to take definitive conclusions based on the results of this research project, it is possible to say that economic and financial sustainability of cork oak forest depend mainly upon the price of cork which depends of its quality and the value that society ascribe to the goods and services provided by forest as a multi-functional production system.

The management techniques that farmers will use may be determinant on the quantity and quality of goods and services produced by cork oak forests. But farmers as entrepreneurs, choose the most profitable management technique. Therefore, government policies may have a crucial role on 'montado' sustainability

1 Policies may incentive continuous crown cover management oriented for cork production and positive externalities desirable for the society.

2 Incentive undercover activities related to grazing (for instance, giving high subsidies to animal production, as it is being done presently) which leads to a lack of regeneration and the consequent disappearance of the crown cover with the degradation of the forest production system.

On the other hand, the investment on cork oak forest also depend upon the rate of return on financial markets which will influence the rate of return farmers will want to obtain from forest investment. As cork oak forest investments have long-run maturity, government credit policies can be determinant on the sustainability of agro-silvopastural production systems. If 'montado' becomes unprofitable, farmers will cease the use of sustainable management techniques which would lead to stands invasion by shrubs and other oaks increasing competition and the risk of forest fire and the consequent disappearance of this type of forest.

\section{References}

Brunson, M.W. (1993) 'Socially acceptable forestry: what does it imply for ecosystem management?', Western Journal of Applied Forestry, Vol. 8, pp.116-119.

Bullard, S.H. and Straka, T.J. (1993) 'Basic concepts in forest valuation and investment analysis', Copyright Bullard-Straka, p.69.

Campos, P., Rodríguez, Y. and Caparrós, A. (2001) 'Towards the dehesa total income accounting: theory and operative Monfragüe study cases', in P. Campos Palacin (Ed.), Special issue Investigación Agraria: Sistemas y Recorsos Forestales - Towards the New Forestlands Commercial and Environmental Benefits Accounting: Theories and Applications, Vol. 1, pp.43-67.

Campos, P. and Caparrós, A. (2006) 'Social and private total hicksian incomes of multiple use forests in Spain', Ecological Economics, Vol. 57, pp.545-557.

Creighton, J.H., Baumgartner, D.M. and Blatner, K.A. (2002) 'Ecosystem management and no industrial private forest landowners in Washington state, USA', Small-Scale Forest Economics, Management and Policy, Vol. 1, pp.55-69.

Díaz, M., Campos, P. and Pulido, F.J. (1997) 'The Spanish dehesas: a diversity in land-use and wildlife', in D.J. Pain and M.W. Pienkowski (Eds), Farming and Birds in Europe. The Common Agricultural Policy and its Implications for Bird Conservation. London, UK: Academic Press, pp.178-209. 
DGF-IFN (2001) 'Distribuição das florestas em Portugal Continental: $3^{\text {a }}$ Revisão do Inventário Florestal Nacional (1995-2000)', Divisão de Inventário e Estatísticas Florestais. Direcção Geral das Florestas. Lisboa.

Groom, B., Hepburn, C., Koundouri, P. and Pearce, D. (2005) 'Discounting the future: the long and the short of it', Environmental and Resource Economics, Vol. 32, pp.445-493.

Gürlük, S. (2006) 'The estimation of ecosystem services' value in the region of misi rural development project: results from a contingent valuation survey', Forest Policy and Economics, Vol. 9, pp.206-218.

Hepburn, C.J. and Koundouri, P. (2007) 'Recent advances in discounting: implications for forest economics', Journal of Forest Economics, Vol. 13, pp.169-184.

Plieninger, T. (2007) 'Compatibility of livestock grazing with stand regeneration in Mediterranean holm oak parklands', Journal for Nature Conservation, Vol. 15, pp.1-9.

Pulido, F.J., Díaz, M. and Hidalgo, S.J. (2001) 'Size structure and regeneration of Spanish holm oak Quercus ilex forests and dehesas: effects of agroforestry use on their long-term sustainability', Forest Ecology and Management, Vol. 146, pp.1-13.

Ribeiro, N.A., Surovy, P. and Oliveira, A.C. (2006) 'Modeling cork oak production in Portugal', in H. Hasenauer (Ed.), Sustainable Forest Management Growth Models for Europe. Berlin, Heidelberg: Springer-Verlag, pp.285-313.

Ribeiro, N.A., Dias, S., Surový, P., Gonçalves, A.C., Ferreira, A.G. and Oliveira, A.C. (2004) 'The importance of crown cover on the sustainability of cork oak stands. A simulation approach', in A.G. Ferreira and S. Schnabel (Ed.), Advances in Geoecology, Vol. 37, pp.275-286.

SROA (1970) Utilização actual do Solo Cartas de Solos e Capacidade de Uso.

\section{Notes}

${ }^{1}$ Mediterranean Cork Oak Forest Programme, http://www.panda.org/about_wwf/where_we_work/ project/projects/index.cfm?uProjectID=9E072.

${ }^{2}$ www.agroreg.uevora.pt. 